\title{
Entrepreneurial Motives and Challenges of SMEs Owners in Emerging Economies: Nigeria \& South Africa
}

\author{
Folashade Akinyemi*, Oluwabunmi Adejumo \\ Institute for Entrepreneurship and Development Studies, Obafemi Awolowo University, Ile-Ife, Nigeria
}

Copyright $@ 2017$ by authors, all rights reserved. Authors agree that this article remains permanently open access under the terms of the Creative Commons Attribution License 4.0 International License

\begin{abstract}
This paper is a comparative analysis of the peculiarities of entrepreneurial motives and challenges that exist in emerging economies. The paper also emphasizes the fact that knowing what entrepreneurs are up against would get them prepared and inexorably minimize the effects of the challenges. Research findings show that entrepreneurs set up business ventures basically for various reasons, and individuals become entrepreneurs primarily due to pull, than push factors. 1200 samples were purposively drawn from two African emerging economies. Pre-tested questionnaires were administered among entrepreneurs in the economic hub to both economies. The analysis was done using descriptive statistics and one-way analysis of variance. The research findings show that a greater proportion of the entrepreneurs in both economies were driven by passion and very few were poverty driven. The results also show that entrepreneurial challenges are typical of every emerging economy but vary in certain cases. Furthermore, the results show that there is a significant difference in the average income level and the number of years in business $(F=7.60 ; p<0.05)$, whereas in South Africa, there is no significant difference in average income level and the number of years in business $(\mathrm{F}=1.41$; $\mathrm{p}>0.05)$. The study concludes that the challenges such as epileptic power supply, lack of finance, and low patronage would continually hamper entrepreneurial activities and inexorably increase the failure rates of entrepreneurship in these economies if the challenges persist.
\end{abstract}

Keywords Entrepreneurial Motives, Entrepreneurial Challenges, SMEs, Emerging Economies

\section{Introduction}

Many countries at different stages of development have recognized the importance of entrepreneurship in the economy. Entrepreneurship has been identified as a necessary tool that enhances job creation, alleviates poverty, and facilitates national economic growth [1]. Countries with higher entrepreneurial activities have absorbed substantial amounts of human and material resources, and in turn experienced growth [2, 3].

However, in emerging economies, only a select few survive the entrepreneurial process. Some entrepreneurs survive from start-up phase through to the established phase, while others do not. Research findings show that $60 \%$ of South African small businesses fail within the first five years of operation [4] and more than $50 \%$ of Nigerian businesses fail with a similar time period [5]. These figures have since increased to $80 \%[6,7]$ and $78 \%[8,9]$, respectively.

Sustaining businesses in emerging economies is a herculean task. Entrepreneurs encounter various challenges in their daily activities [10, 11, 12]. These challenges cannot all be solved at the same time. They have to be handled constructively for the businesses to grow. But unfortunately, only a select few are able to cope with the challenges and only a few have been known to succeed [13, 14, 15]

Furthermore, the choice of two emerging economies in Africa, South Africa and Nigeria, is aimed at understanding the importance of both converging and diverging peculiarities in these two economies for entrepreneurship drive. South Africa and Nigeria are two countries of very high economic relevance in Africa and the globe. Despite this, there are variations in the basic entrepreneurship structure of both countries. Entrepreneurs in Nigeria experience constant power outage, unstable banking systems and financial institutions; and access to credit facilities [16, 17, 9] while their counterparts in South Africa enjoy stable electricity supply, they have well regulated banking systems, and access to finance [18, 19]. It is therefore necessary to understand how differently the impediments affect entrepreneurial activities. Moreover, knowing what the entrepreneurs are up against would get them prepared and help minimize the effects of the challenges.

Nigeria and South Africa are emerging economies in 
Africa. They have large markets for goods and services, and their entrepreneurs have the ability to compete globally if given adequate support [19, 20, 21]. Therefore this study ascertains the entrepreneurial challenges faced by Nigerian and South African entrepreneurs while conducting their businesses. This study also examines the entrepreneurial motives of the SME owners in each economy.

\section{Literature Review}

\subsection{Entrepreneurship in Emerging Economies}

Emerging economies are sometimes referred to as developing nations. They are nations with relatively low gross national product, low per capita income and low gross domestic product when compared with the industrialized nations [22, 23, 24]. Lots of entrepreneurial activities take place at the informal sector but are not reflected in the national growth index such as gross domestic product and gross national product. In developing nations the infrastructural facilities, enabling environment, and social values for entrepreneurship need lots of improvement.

Although entrepreneurial activities are being encouraged in emerging economies, poor implementation policies and corruption has continued to erode the benefits that should have been derived from entrepreneurship. For instance, entrepreneurship education has been introduced in schools, colleges, and higher institutions. Incubation Centres and Entrepreneurship Clubs are also being established to promote entrepreneurship. Many emerging economies have implemented economic reform policies aimed at alleviating problems such as poverty, poor infrastructure, and overpopulation. But, the impacts of such policies are yet to be felt at the grassroots. Hence, most of the Small and Medium Scale Enterprises (SMEs) set up by the entrepreneurs hardly grow.

SMEs constitute the majority of businesses in many countries. Incidentally, there is no one basic definition of SMEs because economies differ and the realities that exist vary from one industrial sector to another. Hence, the definition and classification of SMEs vary from country to another. In some countries, annual turnover, fixed asset base, number of employees, and capital base are some of the criteria used in classifying businesses as micro, small, and medium enterprises. For instance, in Nigeria, using the number of employees, SMEs are defined as businesses having between 1-300 employees [54] but in South Africa, SMEs are businesses having between 1-200 employees [53]. However, for this study, the World Bank classification, as shown in Table 1, was adopted in order to ensure uniformity and make comparisons easier $[55,56]$
Considering the predicaments of entrepreneurs and SME owners in these economies, the question that comes to mind therefore is 'Are these challenges the same in emerging economies'. Hence, this study examines the motives for starting businesses and the challenges encountered by entrepreneurs in Nigeria and South Africa.

Table 1. Classification of firms

\begin{tabular}{|c|c|}
\hline Firms & Number of Employees \\
\hline Micro & $1-9$ \\
\hline Small & $10-50$ \\
\hline Medium & $50-200$ \\
\hline
\end{tabular}

\subsection{Motive Classification of Entrepreneurs}

Entrepreneurs set up business ventures basically for various reasons. Gilad \& Levine [25] proposed the push and pull theories of entrepreneurial motivation. The pull theory argues that individuals conduct entrepreneurial activities because of personal motives such as self-fulfillment, wealth, and independence. The push theory contends that individuals are pushed into entrepreneurship by negative external forces such as unemployment, insufficient salaries, and job dissatisfaction [26]. Research findings show that individuals become entrepreneurs primarily due to pull, than push factors.

The business ventures, however, could start as mice, gazelles, or elephants [27, 28, 29]. The mice are micro or small businesses such as the corner barbershops, and retail outlets with less than 20 employees. Gazelles start out small but grow at a phenomenal rate [30]. Birch \& Medoff [31] defines gazelles as enterprises whose revenue double every four years, and are responsible for $70 \%$ of all new jobs. They are identified by their rapid expansion, job creating abilities, and sales volume [32, 33]. They can be retail shops, wholesale outlets, manufacturing companies, and service companies with staff strength of 20-500 employees. Lastly, the elephants are the big or large corporations, with at least 500 workers that often become multinationals. The businesses are so called because of their sizes, growth rates, staff strength, and number of branches, but the two start-up motives describe the business owners as lifestyle entrepreneurs and gazelle entrepreneurs.

\subsubsection{Lifestyle Entrepreneurs}

Lifestyle entrepreneurs set up businesses in order to maintain a comfortable and exiting lifestyle [34,35]. They are often driven by non-monetary incentives such as tax benefits, personal standards, and independence. They are sometimes referred to as necessity entrepreneurs. They are attracted into entrepreneurship because their personal-drive for wealth, self-fulfillment, and other desirable outcomes $[36,37]$ which explains the pull theory. 


\subsubsection{Gazelle Entrepreneurs}

Gazelle entrepreneurs are driven by a different set of 'forces' prompting them to move from one business start-up to another, with a well-defined growth plan and exit strategy. They lookout for opportunities, and are pushed into entrepreneurship by negative external forces such as job dissatisfaction, inflexible work schedule, and insufficient income [38, 26]. They sometimes display the attributes of serial entrepreneurs. They are the 'fast runners' in the business world that create not only wealth for themselves, but also create safe spaces for other businesses to thrive and survive.

Gazelle entrepreneurs can be telecom wholesale traders, auctioneers, electronic suppliers, online publishers, and vendors of groceries, delicacies or fruits. They could also set-up Internet ventures, as well as software suppliers [39]. Acs \& Mueller [32] also confirms that gazelles are high-impact firms. Hence, gazelle entrepreneurs establish the economies most productive enterprises

\subsection{Entrepreneurial Challenges}

Entrepreneurial challenges, also known as constraints, are the absence or scarcity of resources needed for business growth $[8,40,11]$. Entrepreneurial challenges are the difficulties that militate against entrepreneurship activities. They are the difficulties entrepreneurs encounter while conducting business activities. Entrepreneurial challenges can also be described as the inadequacy or short supply of resources.

World over, some of the specific challenges entrepreneurs face include: lack of finance, inadequate infrastructures, poor management practices, cultural barriers, and unstable environment. Other challenges hindering business growth are lack of entrepreneurship skills, and taxes. Larossi \& Clarke [41] examined the severity of eighteen constraints on business operations in Nigeria and found out that electricity, finance, and tax rates were among the top ten serious constraints. Herrington et al [19] identified fourteen key factors constraining entrepreneurship in South Africa. Olawale \& Garwe [42] identified 30 constraints and grouped the constraints into five main groupings using the principal component analysis.

Therefore, this study will focus on the Entrepreneurial challenges in two emerging African economies only. Table 2 shows some challenges identified in emerging economies.

\section{Methodology}

The first stage of the sampling process was defining the target population [43]. It involves identifying the group of people to be studied, which in this case, comprises of entrepreneurs in emerging economies of Nigeria and South Africa. Next is the sample frame, which involves making a list of places where samples are drawn. Ideally, the sample frame for this study should be a list of entrepreneurs in Lagos and Johannesburg. Since the list of entrepreneurs was not available, purposive sampling technique was used to select entrepreneurs in both cities. Samples for this study were entrepreneurs in Lagos and Johannesburg. This comprises of adults between 18-64years as adopted by the Global Entrepreneurship Monitor [22]. Also, the entrepreneurs were owners of small and medium scale enterprises.

The entrepreneurs were contacted face-to-face and via phone calls. Most of the participants were contacted on two to three occasions before the questionnaire fully completed. The respondents specified their convenient time for the questionnaire administration and the overall response rates were high. However, on many occasions, the field workers had to wait for the participants to attend to their customers before continuing the interview.

A total of 1200 questionnaires were administered. And since the estimated figures obtained from the extant literature revealed that there were more entrepreneurs in Lagos than in Johannesburg, 550 questionnaires were administered in Johannesburg and 650 were administered in Lagos. The analysis was done using descriptive statistics and one-way analysis of variance (ANOVA). Descriptive statistics technique includes: mean, median, the use of graphs, charts, and histograms in describing and summarizing events or activities in statistical terms. It is a bridge between qualitative and quantitative research [50,51,52]. Furthermore, one-way analysis of variance (ANOVA) was used to determine whether there are any statistically significant differences between the income levels of entrepreneurs and number of years in business in both economies.

Table 2. Entrepreneurial Challenges in Emerging Economies

\begin{tabular}{|c|c|c|c|}
\hline 1 & Lack of access to finance & 11 & High inflation rate \\
\hline 2 & Insufficient government support & 12 & Poor roads \\
\hline 3 & High Interest rates & 13 & Poor telecommunication \\
\hline 4 & Bad credit record & 14 & Lack of training \\
\hline 5 & Lack of information technology & 15 & Poor electricity supply \\
\hline 6 & High production costs & 16 & High registration and licence costs \\
\hline 7 & High taxes and other tariffs & 17 & Founder not familiar with market/industry \\
\hline 8 & Inadequate demand & 18 & Economic recession \\
\hline 9 & Lack of networking & 19 & Inadequate market research \\
\hline 10 & Shortage of skilled labour & 20 & \\
\hline
\end{tabular}

Source: Developed for this study based on the various ideas [42, 19, 44, 45, 46, 47, 48, 49] 


\section{Presentation \& Discussion of Findings}

\subsection{Background Information on Entrepreneurs and Business Enterprises}

In total, 1200 questionnaires were administered but the valid returned questionnaires totalled 1148, with 609 coming from Nigeria and 539 returned in South Africa. Tables 2 and 3 present the background characteristics of the sampled entrepreneurs and information on their business enterprises. In terms of business ownership, the bulk of the enterprises in both countries were owned by male $(63 \%$ in Nigeria and $62 \%$ in South Africa). The median age of the sampled entrepreneurs was very close in both countries (31 years in Nigeria compared with 32 years in South Africa). The age distribution leaned favorably towards the younger age range of 18-33years constituting relatively more than half of the sampled entrepreneurs (53\% in Nigeria and 51\% in South Africa). More than one-fourth are aged $34-41$ years, and only about $6 \%$ in Nigeria and $7 \%$ in South Africa were aged 50 years or more.

About 27\% of entrepreneurs sampled in Nigeria and $34 \%$ of those sampled in South Africa had a university degree, only 2\% of entrepreneurs in Nigeria and about 10\% in South Africa had a post-graduate degree. Relatively among the sampled individuals, those in South Africa showed a higher proportion of those with at least a university degree than their counterparts from Nigeria. This is not surprising because, a large percentage of the business owners in Lagos are Ibos who would rather learn a trade and go straight into business, than get a degree in college.

Table 3. Characteristics of Sampled Entrepreneurs in Nigeria and South Africa

\begin{tabular}{|c|c|c|c|c|}
\hline \multirow[b]{2}{*}{ VARIABLES } & \multicolumn{2}{|c|}{ NIGERIA } & \multicolumn{2}{|c|}{ SOUTH-AFRICA } \\
\hline & $\begin{array}{c}\text { FREQUENCY } \\
\mathrm{N}=609\end{array}$ & PERCENT & $\begin{array}{c}\text { FREQUENCY } \\
\mathrm{N}=539\end{array}$ & PERCENT \\
\hline \multicolumn{5}{|c|}{ Gender } \\
\hline Male & 385 & 63.2 & 336 & 62.3 \\
\hline Female & 224 & 36.8 & 203 & 37.7 \\
\hline \multicolumn{5}{|c|}{ Age in Years } \\
\hline $18-24$ & 80 & 13.3 & 65 & 12.1 \\
\hline $25-33$ & 238 & 39.6 & 209 & 38.9 \\
\hline $34-41$ & 159 & 26.5 & 155 & 28.8 \\
\hline $42-49$ & 87 & 14.5 & 70 & 13.0 \\
\hline $50-57$ & 24 & 4.0 & 27 & 5.0 \\
\hline $58-65$ & 13 & 2.2 & 12 & 2.2 \\
\hline Median Age & \multicolumn{2}{|c|}{31.2 years } & \multicolumn{2}{|c|}{32.4 years } \\
\hline \multicolumn{5}{|c|}{ Academic Qualification } \\
\hline Below First Degree & 421 & 71.0 & 299 & 56.1 \\
\hline First Degree & 162 & 27.3 & 183 & 34.3 \\
\hline Masters & 8 & 1.4 & 43 & 8.1 \\
\hline $\mathrm{PhD}$ & 2 & 0.3 & 8 & 1.5 \\
\hline \multicolumn{5}{|c|}{ Nationality } \\
\hline Nigeria & 589 & 97.9 & 90 & 17.7 \\
\hline South Africa & 5 & 0.8 & 280 & 54.9 \\
\hline Other & 13 & 2.4 & 168 & 31.2 \\
\hline \multicolumn{5}{|c|}{ Religion } \\
\hline Christianity & 474 & 77.9 & 407 & 75.5 \\
\hline Islam & 122 & 20.0 & 47 & 8.7 \\
\hline Others & 13 & 2.1 & 83 & 15.4 \\
\hline
\end{tabular}


Table 4. Distribution by Information on Business Enterprise

\begin{tabular}{|c|c|c|c|c|}
\hline \multirow[b]{2}{*}{ VARIABLES } & \multicolumn{2}{|c|}{ NIGERIA } & \multicolumn{2}{|c|}{ SOUTH-AFRICA } \\
\hline & $\begin{array}{c}\text { FREQUENCY } \\
\mathrm{N}=609\end{array}$ & PERCENT & $\begin{array}{c}\text { FREQUENCY } \\
\mathrm{N}=539\end{array}$ & PERCENT \\
\hline \multicolumn{5}{|c|}{ Type of Business } \\
\hline Food & 104 & 17.4 & 103 & 19.3 \\
\hline Textile & 77 & 12.9 & 80 & 15.0 \\
\hline Wood & 43 & 7.2 & 21 & 4.0 \\
\hline Pharmaceuticals & 43 & 7.2 & 7 & 1.3 \\
\hline Metal & 75 & 12.5 & 25 & 4.7 \\
\hline Telecommunication & 74 & 12.4 & 49 & 9.2 \\
\hline Service & 182 & 30.4 & 250 & 46.7 \\
\hline \multicolumn{5}{|c|}{ Is this your first business? } \\
\hline No & 153 & 25.7 & 172 & 33.1 \\
\hline Yes & 442 & 74.3 & 348 & 66.9 \\
\hline \multicolumn{5}{|c|}{ If no, what happened to your previous business? } \\
\hline Stopped & 85 & 60.3 & 73 & 45.9 \\
\hline Sold & 3 & 2.1 & 10 & 6.3 \\
\hline Still operating & 46 & 32.6 & 60 & 37.7 \\
\hline Transferred & 7 & 5.0 & 16 & 10.1 \\
\hline
\end{tabular}

The information on the business enterprises (Table 4) shows the seven major classifications of entrepreneurial activities in both economies namely: food, textile, pharmaceuticals, metal, wood, telecommunication and services. The three most populous sectors in both economies were the service, food, and textile sectors, respectively. The service sector (30\% in Nigeria and $47 \%$ in South Africa) comprised of businesses such as hairdressing salons, medical practitioners, and day care centres. The food sector (17\% in Nigeria and 19\% in South Africa) was dominated by restaurant owners, fruits, and raw food sellers. The textile businesses (13\% in Nigeria and $15 \%$ in South Africa) included cloth manufacturing companies, dressmakers and sellers.

A striking feature in the distribution of entrepreneurs' nationality, as shown in Figures 1 and 2, is that whereas only about $3 \%$ of entrepreneurs sampled in Nigeria are foreigners, about $45 \%$ of entrepreneurs sampled in South Africa are foreigners; incidentally Nigerians constitute about $18 \%$ of foreign entrepreneurs among the sampled population in South Africa. And most of the Nigerian entrepreneurs in South Africa are Ibos. But only about 1\% of the sampled respondents in Nigeria reported that they are South Africans.

The results further reiterate the fact that Johannesburg is a metropolis with many foreigners such as Pakistanis, Indians, and Israelis who have become South African citizens. South Africa is also known for its cultural diversities and has 11 official languages but the Xhosas are the most business-inclined among the indigenous South Africans. The sampled population by religion is
Christian-dominated $(78 \%$ in Nigeria and $76 \%$ in South Africa).

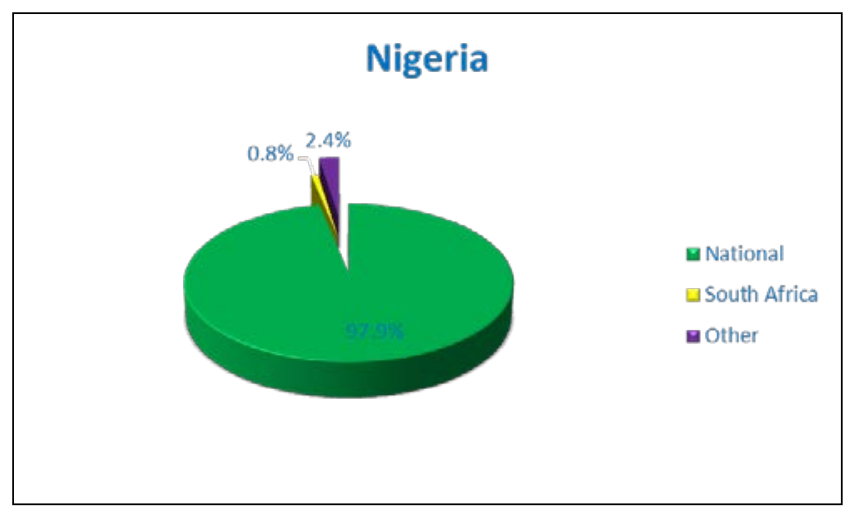

Figure 1. Nationality of Respondents in Lagos (Nigeria)

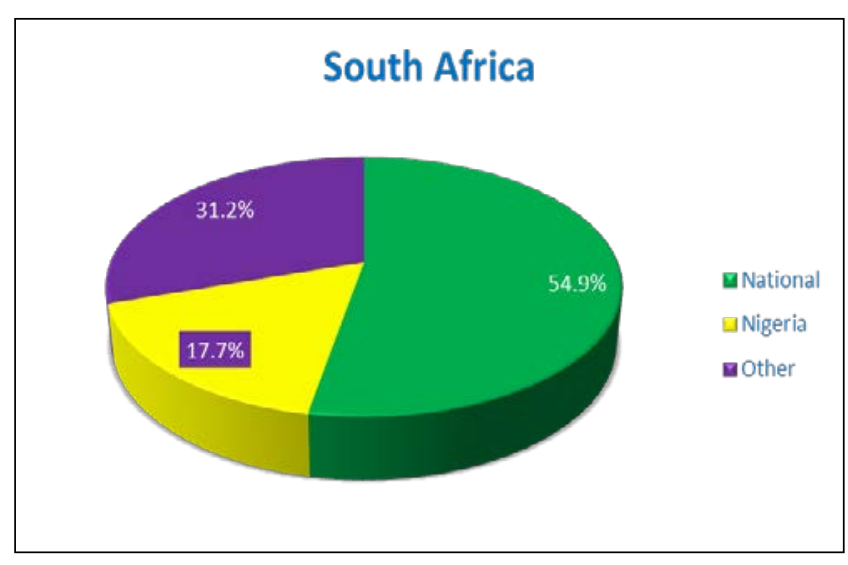

Figure 2. Nationality of Respondents in Johannesburg (South Africa) 
A large percentage of business owners in Johannesburg are foreigners (Figure 2) and are in the firm birth and persistence phases. A major explanation of this is the aftermath of the promulgation of apartheid in 1994. South Africa's borders were opened to the world and has since then been experiencing the influx of various nationals who now see South Africa as a fertile ground for various economic activities and are now coming in to set up businesses.

Also, most of the established businesses in South Africa's commercial hub (Johannesburg) where the study was conducted are franchise businesses, owned by foreigners, and housed in big shopping malls whereas Nigeria's commercial hub (Lagos), where the study was conducted, has lots of micro, small, and medium scale enterprises owned by Nigerians. Unlike South Africa with many big shopping malls and departmental stores, the selected sites in Nigeria only recorded four major shopping malls.

\subsection{Motive for Starting Businesses in Each Economy}

A greater proportion of the entrepreneurs in both economies (45.9\% in Nigeria and $40.1 \%$ in South Africa) were driven by passion for the business and very few were poverty driven (3.6\% in Nigeria and 2.8\% in South Africa) as presented in Figure 3 below. Other reasons specified (16.6\% in Nigeria and $23.1 \%$ in South Africa) included marital constraints, raising fund to further one's education, meeting the needs in a particular location, and migration.

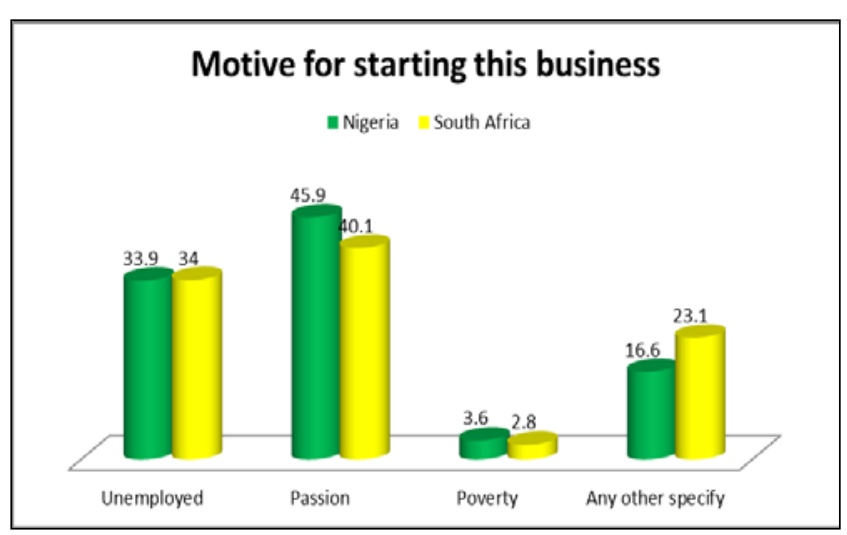

Figure 3. Motive for Starting Businesses in Nigeria and South Africa

Although the extant literature classified entrepreneurs' motive for starting businesses into two main categories (opportunity and necessity entrepreneurs), and noted that countries with higher percentage of necessity entrepreneurs have higher business failure rates [49] many other factors also contribute to the high business failure rates in emerging economies. The high failure rates observed in some studies $[6,15,9]$ were not only due to the entrepreneurs' motive for starting businesses but were due to other factors such as mismanagement, financial and environmental constraints.
The findings from this study show that passion is the major driving force among the entrepreneurs in both economies thereby giving greater prospects for lesser business failure rates. Besides, most of the entrepreneurs who went into business because of other reasons added that they saw more reasons to continue their businesses even after their initial motives has been satisfied. Hence, if there is an amelioration of the various impediments to entrepreneurial development, it is expected that the business failure rates in these economies would plummet.

\subsection{Sizes of Businesses in Nigeria and South Africa}

Using the World Bank classification of firms, it was imperative to examine the sizes of businesses operated by the entrepreneurs, and whether despite the challenges, some entrepreneurs graduated from one phase to another by increasing their staff strength over the years. The basic argument, as shown in the extant literature, was that increase in profit figure or sales volume alone was not enough evidence that growth has occurred. Hence, the entrepreneurs' levels of income were examined as well as their staff strength. Looking at the staff strength (Figure 4) when the businesses started, and when the data was collected, there were indications that some entrepreneurs transited from one phase to another.

In other words, some levels of growth, no matter how small, occurred in both economies, which are directly linked to the ability of entrepreneurs to transit from one phase to another, vertically. In addition to the increase in revenue, their scopes of operations increased, necessitating them to employ more workers. Hence, some moved up the ladder from micro, to small, to medium, and big businesses. The proportion of those having 10-49 workers at inception increased in both countries from $5.3 \%$ to $12.3 \%$ in Nigeria and $3.7 \%$ to $16.7 \%$ in South Africa. This implies that some of the entrepreneurs, who were previously at the 1-9 workers' category, moved to the 10-49 workers' category. However, in both countries, there were remarkable reductions in the staff strength at inception and when the data was collected. For instance, as shown in figure 4, the $87 \%$ and $82.6 \%$ of business owners in Nigeria and South Africa having 1-9 workers at inception, reduced to $70.8 \%$ and $68.5 \%$, respectively. This suggests that the challenges were more overwhelming at inception than at later stages when the entrepreneurs have become more conversant with the business environment.

Also, the proportion of businesses with staff strength of 50-199 workers increased in both countries but narrowly dropped from $10.8 \%$ to $10.2 \%$ for businesses having more than 200 workers in South Africa. Overall, the growth rates in Nigeria are generally higher than in South Africa, and the rates in both economies reduced at the medium and big business cadres.

Using One-way Analysis of Variance (ANOVA) to 
examine the differences in average income levels of entrepreneurs across number of years in business in both Nigeria and South Africa, the result shows that in Nigeria, there is a significant difference in the average income level and the number of years in business $(\mathrm{F}=7.60 ; \mathrm{p}<0.05)$, whereas in South Africa, there is no significant difference in average income level and the number of years in business ( $\mathrm{F}=1.41 ; \mathrm{p}>0.05)$. However, in the pooled data, a significant difference exists in the average income level and the number of years in business $(F=4.12 ; \mathrm{p}<0.05)$.

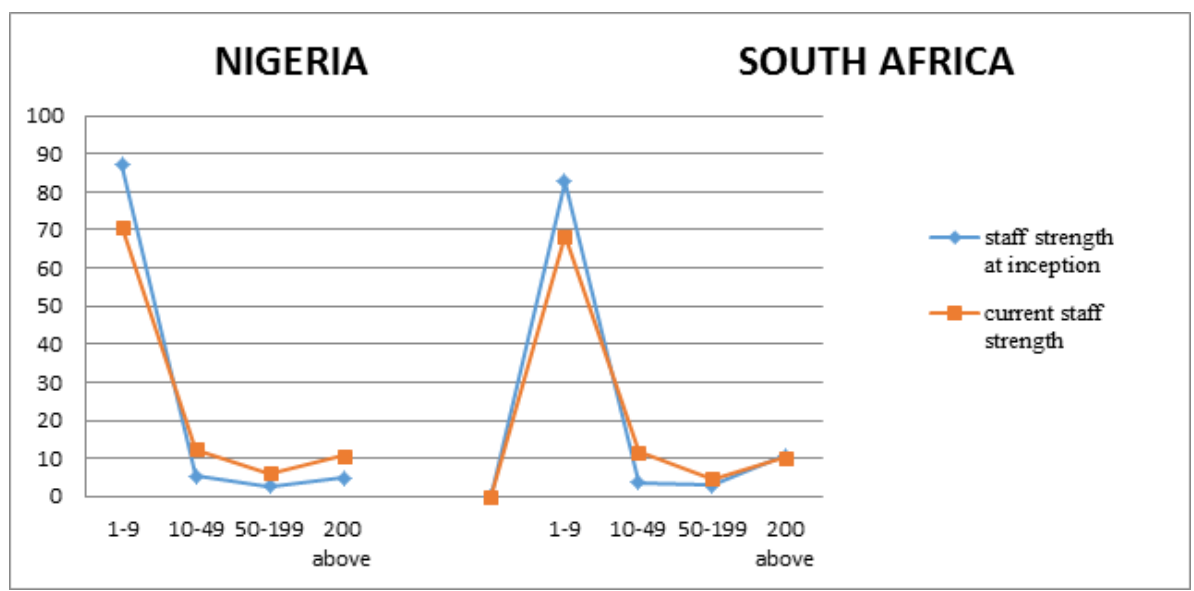

Figure 4. Size of Businesses in Nigeria and South Africa

Table 5. One-way Analysis of Variance

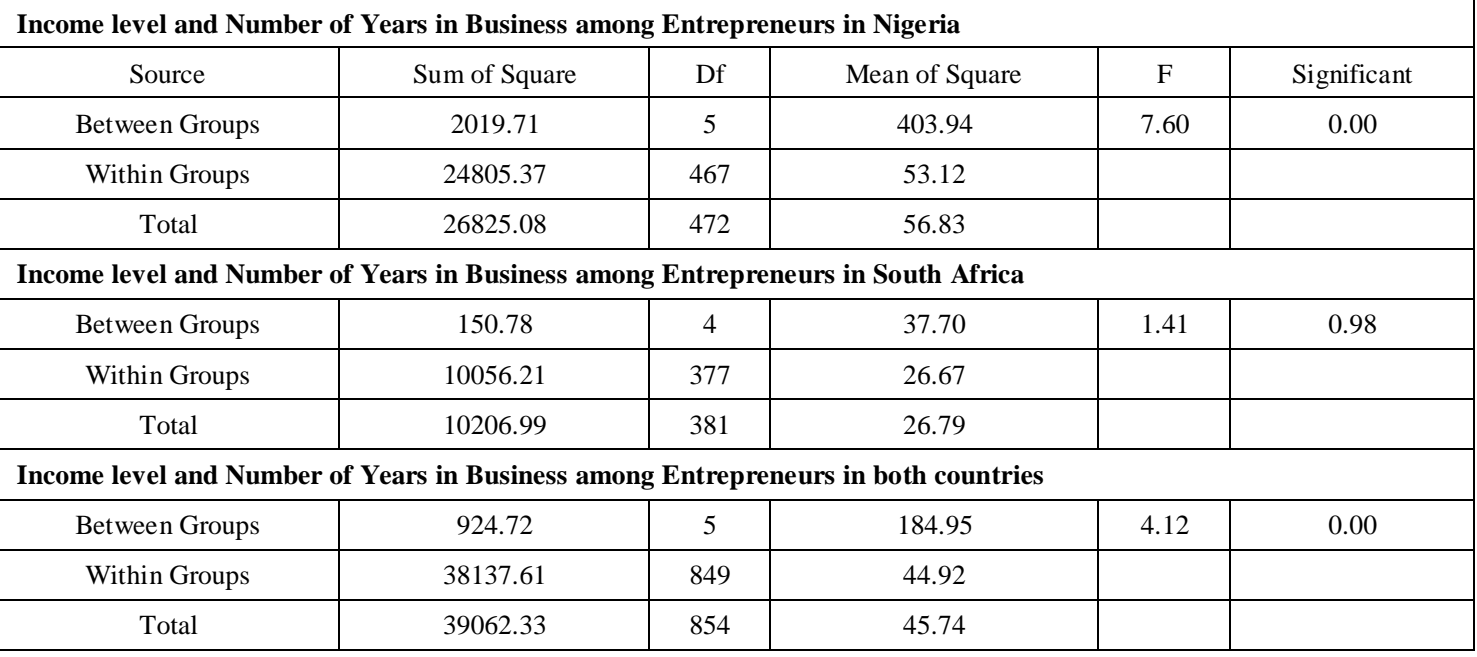

Challenges faced when starting this business by country

- Nigeria South Africa

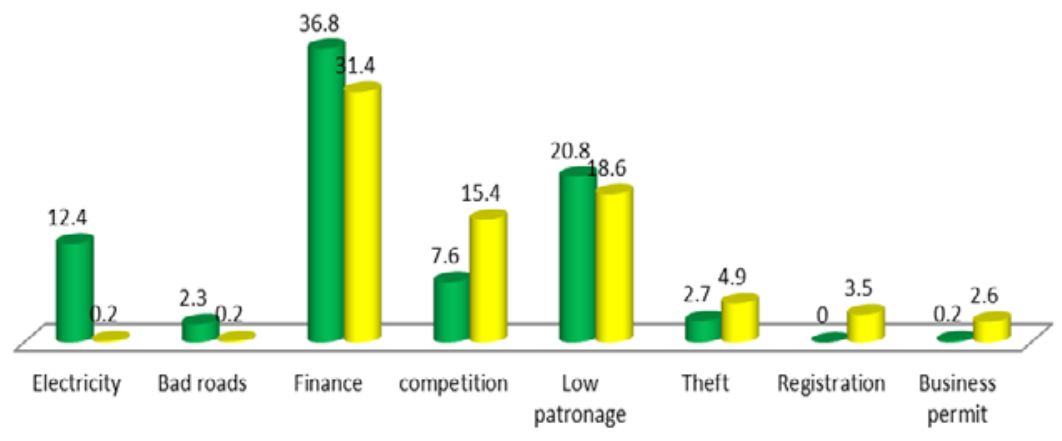

Figure 5. Challenges Faced when Starting Businesses in Nigeria and South Africa 


\subsection{Peculiarity of Entrepreneurial Challenges}

This findings shows that entrepreneurial challenges are typical of every emerging economy but vary in certain cases as reported in Figure 5. Some challenges were very minimal in Nigeria but quite significant in South Africa and vice versa. However, lack of funds was the most pressing challenge in both countries $\mathbf{3 6 . 8 \%}$ in Nigeria and $31.4 \%$ in South Africa), followed by low patronage (20.8\% in Nigeria and $18.6 \%$ in South Africa). The two main causes of low patronage, as explained by the respondents, were the general economic hardship in both countries, and high level of competition. Thirdly, the respondents in Nigeria further emphasized adverse effects of the epileptic power supply on their businesses while their South African counterparts implicated stiff competition from similar business ventures since inception.

\section{Conclusions}

The study shows that a greater proportion of the entrepreneurs in Nigeria and South Africa are passion driven and very few are poverty driven. This implies that most of them are pulled, not pushed, into entrepreneurship. The results also show that entrepreneurial challenges are typical of every emerging economy but vary in certain cases. Some challenges were very minimal in Nigeria but quite significant in South Africa and vice versa. However, the challenges would continually hamper entrepreneurial activities, and inexorably increase the failure rates of entrepreneurship in these economies if the challenges persist.

\section{Recommendation}

Knowing what the entrepreneurs are up against would get them prepared and help minimize the effects of the challenges. The study therefore recommends that all hands should be on deck, at both micro and macro levels, to create more enabling environment for businesses to thrive. Also, individuals, government, and relevant stakeholders should provide support for entrepreneurs in their economies. And on the other hand, business owners and entrepreneurs should pursue optimum production costs, and ensure maximum utilization of the available resources to enhance their businesses. Finally, the entrepreneurs should be innovative and adopt more proactive approaches to grow their businesses.

\section{REFERENCES}

[1] Thurik, A. R., Carree, M. A., Van Stel, A., \& Audretsch, D. B, Does Self-Employment Reduce Unemployment? Journal of Business Venturing, 23(6), 673-686, 2008.

[2] Baumol, W. J., \& Strom, R. J., Entrepreneurship and Economic Growth, Strategic Entrepreneurship Journal, 1(3-4), 233-237, 2007.

[3] Moufawad, P. M., Entrepreneurship and Economic Growth, Masters of Arts in Financial Economics, American University of Beirut, Bierut, Lebanon, 2012.

[4] Ligthelm, A., Measuring the Size of the Informal Sector in South Africa, 2004/05 (pp. 1- 94). Pretoria: Bureau of Market Research, University of South Africa, 2005.

[5] Martin, O. N., Fraud, Greed or Entrepreneurship? Reappraising Nigeria's Market Economy, Economic Reflections, B(9), 1-8, 2008.

[6] Woodward, D., Rolfe, R., Ligthelm, A. A., \& Guimaraes, P, The Viability of Informal Microenterprise in South Africa, Journal of Developmental Entrepreneurship, 16(1), 65-86, 2011.

[7] Strydom, J. W., Tracking Study on Skills Development and Employment Generation of Small Retail Establishments in Mamelodi, Tshwane, Southern African Business Review, 9 (3), 15- 22, 2005.

[8] Ihua, U. B., SMEs Key Failure-Factors: A Comparison between United Kingdom and Nigeria, Journal of Social Science, 18(3), 199-207, 2009.

[9] Eneh, O. C., Survival Strategies for Entrepreneurs in Dwindling Nigerian Economy, Asian Journal of Industrial Engineering, 2(2), 52-62, 2010.

[10] Brink, A., Cant, M., \& Ligthelm, A., Problems Experienced by Small Businesses in South Africa, Paper presented at the 16th Annual Conference of Small Enterprise Association of Australia and New Zealand, University of Ballarat, Ballarat, Australia, 2010.

[11] Luthans, F., Stajkovic, A. D., \& Ibrayeva, E., Environmental and Psychological Challenges Facing Entrepreneurial Development in Transitional Economies, Journal of World Business, 35(1), 95-110, 2000.

[12] Chu, H. M., Kara, O., \& Benzing, C., An Empirical Study of Nigerian Entrepreneurs: Success, Motivations, Problems, and Stress, International Journal of Business Research, 8(2), 1-11, 2008.

[13] Van Eeden, S., Viviers, S., \& Venter, D., A Comparative Study of Selected Problems Encountered by Small Businesses in the Nelson Mandela, Cape Town and Egoli Metropolis. Management Dynamics, Journal of the Southern African Institute for Management Scientists, 12(3), 3-23, 2003.

[14] Ligthelm, A. A., Size Estimate of the Informal Sector in South Africa, South African Business Review, 10(2), 32-53, 2006.

[15] Ligthelm, A. A., Entrepreneurship and Small Business Sustainability, Southern African Business Review 14(3), 131-153, 2010.

[16] Ofili, O. U, Challenges facing entrepreneurship in Nigeria. International Journal of Business and Management, 9(12), 258, 2014. 
[17] Ihugba, O. A., Odii, A., \& Njoku, A. C., Challenges and prospects of entrepreneurship in Nigeria, Academic Journal of Interdisciplinary Studies, 2(5), 25, 2013.

[18] Herrington, M., Kew, J., Kew, P., \& Monitor, G. E., Tracking entrepreneurship in South Africa: A GEM perspective. South Africa, Graduate School of Business, University of Cape Town, 2010.

[19] Herrington, M., Kew, J., Simrie, M., \& Turton, N., Global Entrepreneurship Monitor 2011 Report for South Africa (pp. 1-74), 2011.

[20] Marr, J., \& Reynard, C., Investing in Emerging Markets: The BRIC Economies and Beyond, Uk: John Wiley \& Sons Ltd, 2010.

[21] Agboli, M. \& Ukaegbu, C. C., Business Environment and Entrepreneurial Activity in Nigeria: Implications for Industrial Development, Journal of Modern African Studies, 44(1), 1-30, 2006.

[22] Kelly, D. J., Singer, S., \& Herrington, M., The Global Entrepreneurship Monitor: 2011 World Report (pp. 1-39), 2011.

[23] Minniti, M., Bygrave, W. D., \& Autio, E., Global Entrepreneurship Monitor: 2005 Executive Report, 2005.

[24] Vijayakumar, N., Perumal, S., \& Rao, K. C., Determinants of FDI in BRICS Countries: A Panel Analysis. International Journal of Business Science and Applied Management, 5(3), 1-13, 2010.

[25] Gilad, B., \& Levine, P., A Behavioural Model of Entrepreneurial Supply, Journal of Small Business Management, 24(4), 45-54, 1986.

[26] Segal, G., Borgia, D., \& Schoenfeld, J., The Motivation to Become an Entrepreneur, International Journal of Entrepreneurial Behaviour \& Research, 11(1), 42-57, 2005.

[27] Reynolds, P. D., \& Curtin, R., Business Creation in the United States: Panel Study of Entrepreneurial Dynamics II Initial Assessment, Foundations and Trends in Entrepreneurship, 4(3), 155-307, 2008.

[28] Wong, P. K., Ho, Y. P., \& Autio, E., Entrepreneurship, Innovation and Economic Growth: Evidence from GEM Data, Small Business Economics, 24(3), 335-350, 2005.

[29] Delmar, F., \& Davidsson, P., High-Growth Firms and Their Contribution to Employment: The Case of Sweden 1987-96, In P. Davidxxon, F. Delmar \& J. Wiklund (Eds), Entrepreneurship and the Growth of Firms, Cheltenham: Elgar, 2006.

[30] Henrekson, M., \& Johansson, D., Gazelles as Job Creators: A Survey and Interpretation of the Evidence, Small Business Economics, 35(2), 227-244, 2010.

[31] Birch, D., \& Medoff, J., 'Gazelles' In Lewis C. Solmon and Alec R. Levenson, Eds., Labour Markets, Employment Policy, and Job Creation159-167, Boulder: Westview Press, 1994.

[32] Acs, Z. J., \& Mueller, P., Employment Effects of Business Dynamics: Mice, Gazelles and Elephants, Small business Economics, 30, 85-100, 2008.

[33] Autio, E., Arenius, P., \& Wallenius, H., Economic Impact of
Gazelle Firms in Finland. Finland: Helsinki University of Technology, Institute of Strategy and International Business, 2000.

[34] Marcketti, S. B., Niehm, L. S., \& Fuloria, R., An Exploratory Study of Lifestyle Entrepreneurship and its Relationship to Life Quality, Family and Consumer Sciences Research Journal, 34(3), 241-259, 2006.

[35] Mottiar, Z., Lifestyle Entrepreneurs and Spheres of Inter-Firm Relations: The Case of Westport Co. Mayo, Ireland, The International Journal of Entrepreneurship and Innovation, 8(1), 67-74, 2007.

[36] Henricks, M., Not Just a Living: The Complete Guide to Creating a Business That Gives You a Life, Cambridge: MA: Perseus, 2002.

[37] Henderson, J., Building the Rural Economy with High-Growth Entrepreneurs, Economic Review, 87(3), 45-70, 2002.

[38] Cunneen, D. J., \& Mererdith, G. G., Entrepreneurial Founding Activities that Create Gazelles, Small and Medium Enterprises, 15(1), 39-59. 2007.

[39] Feindt, S., Jeffcoate, J., \& Chappell, C., Identifying Success Factors for Rapid Growth in SME E-commerce, Small Business Economics, 19(1), 51-62, 2002.

[40] Wickramansinghe, N., \& Sharma, S. K., Key Factors That Hinder SMEs in Succeeding in Today's Knowledge-Based Economy, International Journal of Management and Enterprise Development, 2(2), 141-158, 2005.

[41] Larossi, G., \& Clarke, G. R., Nigeria 2011: An Assessment of the Investment Climate in 26 States, Washington DC: World Bank, 2011.

[42] Olawale, F., \& Garwe, D., Obstacles to the Growth of New SMEs in South Africa: A Principal Component Analysis Approach, African Journal of Business Management, 4(5), 729-738. 2010.

[43] Bhattacherjee, A., Social Science Research: Principles, methods, and practices (2nd Edition.): USF Tampa Bay Open Access Textbooks Collection. Book 3, 2012.

[44] Elkan, W., Entrepreneurs and Entrepreneurship in Africa, Research Observer, 3(2), 171-188, 1988.

[45] Greve, A., \& Salaff, J. W., Social Networks and Entrepreneurship, Entrepreneurship Theory and Practice, 28(1), 1-22, 2003.

[46] Renski, H., New Firm Entry, Survival, and Growth in the United States. Journal of the American Planning Association, 75(1), 60-76, 2009.

[47] Walker, E., \& Brown, A., What Success Factors are Important to Small Business Owners? International Small Business Journal 22(6), 577-594, 2004.

[48] Rauch, A., \& Frese, M., Let's Put the Person Back into Entrepreneurship Research: A Meta-Analysis on the Relationship Between Business Owners' Personality Traits, Business Creation, and Success, European Journal of Work and Organisational Psychology, 16(4), 353-385, (2007).

[49] Bosma, N., \& Levie, J., Global Entrepreneurship Monitor, 2009 Global Report (pp. 8-16), 2010. 
[50] Bryman, A., Integrating Qualitative and Quantitative Research: How is it Done? Qualitative Research 6(1), 97-113, 2006.

[51] Oja, H., Descriptive Statistics for Multivariate Distributions, Statistics \& Probability Letters, 1(6), 327-332, 1983.

[52] Salkind, N. J., \& Rainwater, T., Exploring Research. Prentice Hall Upper Saddle River, NJ, 2000.

[53] Ojah, K., \& Mokoaleli-Mokoteli, T., Possible Effective Financing Models for Entrepreneurship in South Africa: Guides from Microfinance and Venture Capital Finance.
African Finance Journal, 12, 1-26, 2010.

[54] Oliyide, O., Law, Credit Risk Management and Bank Lending to SMEs in Nigeria. Commonwealth Law Bulletin, 38(4), 673-695, 2012

[55] Lal, K., Globalisation and the Adoption of ICTs in Nigerian SMEs. Science Technology \& Society, 12(2), 217-244, 2007.

[56] Keskin, H., \& Şenturk, C. The Importance of Small and Medium-Sized Enterprises (SMEs) in Economies: Swot Analysis of the SME Sector in Turkey and Albania. Niğ de Üniversitesi İIBF Dergisi, 3(1), 116-132, 2010. 